\title{
Travelling another Country: An Exploration into Travel Writings by Bhojpuri Speakers of India
}

\author{
Jullie Rani \\ Centre for Political Studies, School of Social Sciences, Jawaharlal Nehru University, New \\ Delhi, 110067.Email: jullie.jnu@gmail.com
}

\begin{abstract}
Travel writings by Bhojpuri speakers of India define stories of pain and separation, survival of lives in difficult situations and the aspect of being together as a group. In the nineteenth century, Bhojpuri speakers from India were sent to countries such as Mauritius, Fiji, Trinidad, Surinam, and Guyana to work at sugar plantations under a five year agreement during the British rule. These Bhojpuri plantation workers were called girmitiya. In this context, this paper seeks to address issues of Bhojpuri diaspora, defining newer discussions towards political, social and economic and cultural spheres of their lives in another country, through an analysis of travel literature written by them. Ample travel literature has been written by Bhojpuri speakers who went and settled in the respective countries to which they were sent, also called Bhojpuri diaspora. The aspect which makes this work different is that this paper specifically analyzes works of travel to another country written by Indian Bhojpuri speakers and not literature written by Bhojpuri diaspora. The literary works analyzed here are written originally in Hindi and Bhojpuri namely- Fiji mein Kabir Panth ka Udbhav aur Vikas (Development of Kabir's stories in Fiji) by Dr Kamta Kamlesh, Pravasi Bhojpuri ka Antardwand (Dilemma of the Bhojpuri diaspora) by Rasik Bihari Ojha, Pravasi Bhartiya kaha aur kitne (Number and location of the Indian diaspora) by Dr Prakash Chandra Jain and Bhojpuri kshetra ki jatiya pehchaan (Caste identity of Bhojpuri region) by Dr Shri Vilas Tiwary.
\end{abstract}

Keywords: Travel Literature, Pre-Independent Period, Indian Diaspora, Bhojpuri Speakers.

\section{Introduction}

Travel writings often takes us into journeys filled with emotions and adventures. However, along with these aspects, travel discussed in this paper, acompanies with it stories of pain and separation from loved ones. Carl Thompson (2011, p.1) writes in this regard that travel writings have been a popular genre in the contemporary times. This paper attempts to explore travel journeys of the Bhojpuri diaspora. The portions which have been analyzed in this paper are selected parts of the full articles written by Indian Bhojpuri speakers of their journeys, life and settelment' in another country. This paper argues that travel writings are not without their limitations as they are primarily works of 'memory'. A work of travel writing usually constitutes of facts as well as fiction. Within this framework, travel narratives originally written in Bhojpuri and Hindi have been analyzed and presented in this paper.

Dr. Rajeshwari Shandilya argues that Bhojpuri is a language which travelled from various places in India to various islands and established itself at the global level. The travel literature discussed in this work, have been taken from the edited book by Dr Rajeshwari Shandilya, titled Vishwa Vyapini Bhojpuri (Globalised Bhojpuri Language) (2004) which is written originally in Hindi and Bhojpuri. These articles have been written by Indian Bhojpuri speakers and not speakers belonging to the Bhojpuri diaspora. ${ }^{1}$ This paper attempts to fill the gap of various (c) AesthetixMS 2020. This Open Access article is published under a Creative Commons Attribution Non-Commercial 4.o International License (http://creativecommons.org/licenses/by-nc/4.o/), which permits non-commercial re-use, distribution, and reproduction in any medium, provided the original work is properly cited. For citation use the DOI. For commercial re-use, please contact editor@rupkatha.com. 
scholarly works which have been written by the Bhojpuri diaspora, by bringing into discussion works written by Indian Bhojpuri speakers of their travel to another country. In this regard, we consider the jurisdiction of the Bhojpuri region in India as has been defined in Linguistic Survey of India (1903) by George Abraham Grierson. Grierson used the imaginary name 'Bihari' for the three Magadhan dialects - Bhojpuri, Magadhi and Maithili. However, this does not imply that Bhojpuri is only spoken in Bihar in India. As described by Grierson, the Bhojpuri region varies beyond Bihar:

The language called after this locality has spread far beyond its limits. It reaches on the north, across the Ganges, and even beyond the Nepal frontier, up to the lower ranges of the Himalayas, from Champaran to Basti. On the South, it has crossed the Sone, and covers the great Ranchi plateau of Chota Nagpur, where it ultimately finds itself in contact with the Bengalis of Manbhum, and with the Oriyas of Singhbhum. (1903, pp.40-41).

He further argues that among the three dialects, Maithili, Magadhi and Bhojpuri, Bhojpuri cover a vast geographical territory. It begins in the most western part north of the Ganges, lies to the west of the Magadhi of Gaya and Hazaribagh, till it has covered the entire Ranchi plateau. On the South, it is bounded by the Oriya of Singhbhum and the native state of Gangpur. The boundary then turns to the north, through the heart of the Jashpur state, to the western border of Palamu, along which line it marches with the form of Chattisgarhi spoken in Sarguja and western Jashpur. After passing along the western side of Palamu, the boundary reaches the southern border of Mirzapur. South of Mirzapur, it had Chattisgarhi for its neighbor. It has been bounded on the west, first by the Bagheli of Baghelkhand and then by Awadhi. Having crossed the Ganges, its boundary line lies nearly due north to Tanda on the Gogra, in the district of Fyzabad. It has run along the west of Azamgarh and across Fyzabad. At Tanda, its course turns west along the Gogra and then north up to the lower ranges of the Himalayas, so as to include the district of Basti. Beside the area included in the above language frontier, Bhojpuri is also spoken by the members of the wild tribe of Tharus, who inhabit the districts of Gonda and Bahraich. (Grierson, 1903, p.41).

Various aspects of Bhojpuri speakers travelling to 'another country' far away from home, under a five year agreement during the British rule, have been presented in this paper through four different perspectives, namely - Fiji mein Kabir Panth ka Udbhav aur Vikas (Development of Kabir's stories in Fiji) by Dr Kamta Kamlesh, Pravasi Bhojpuri ka Antardwand (Dilemma of the Bhojpuri diaspora) by Rasik Bihari Ojha, Pravasi Bhartiya kaha aur kitne (Number and location of the Indian diaspora) by Dr Prakash Chandra Jain and Bhojpuri kshetra ki jatiya pehchaan (Caste identity of the Bhojpuri region) by Dr Shri Vilas Tiwary. The editor Rajeshwari Shandilya(2004) further writes, a detailed discussion of globalised Bhojpuri society can be analyzed referring to terms such as coolie, majdoor, girmitiya, who were named so during travels to various colonized island countries during the British rule to work as labourers at British plantations. The travel narratives which will be analyzed are selected parts where 'travels' by the narrator have been discussed in the original articles.

\section{Dr. Rasik Bihari Ojha: Pravasi Bhojpuri ka Antardwand}

Dr. Rasik Bihari Ojha 'Nirbhik' (Shandilya, 2004, pp.227-229) writes in his narrative, the word diaspora implies individuals who live in a foreign land but had originally belonged to India. Bhojpuri speakers from India were taken to countries such as Mauritius, Fiji, Trinidad, Surinam, and Guyana to work at sugar plantations under a five year agreement during the British rule in 
India in the nineteenth century. These Indian Bhojpuri speaking labourers were called girmitiya coolies. During their travel to another country, the Bhojpuri speaking Indians carried with themselves The Ramayana, Bhagavat Gita, Hanuman Chalisa,(all sacred Hindu texts), oral traditions, folksongs in Bhojpuri called loriki, songs of marriages, traditions, janeu (a sacred thread), tilak ( a red coloured powder worn by a Hindu on his forehead), and all sorts of folk stories of their Bhojpuri roots. In 1834, Bhojpuri speakers from India emigrated to Mauritius as girmitiya coolies. They not only took the sacred Hindu texts during their travel to another land, they also took with them memories of the Ganga, the holy river of Hindus. They poured ganga jal (Ganga river water, considered as holy water) collected from India, in a random river and called the river Ganga of Mauritius.

In Trinidad, like Mauritius, Bhojpuri speaking Indians were lured into employment as British plantation workers. These Indians travelled in ships to another country, leaving their home country behind. Nirbhik has called this ship 'Palwaali jahaaj' in his work. These Bhojpuri speakers used to refer each other as jahaaji bhai (ship brothers). He narrates that they used to travel for months but could not see the sea shore. All the jahaaji bhais used to cry thinking that it will take long to reach another country.

Bhojpuri speaking workers who went from India to another country, Surinam, were called contractee. In Surinam too, like Mauritius, they used to refer each other as jahaaji bhai. Ojha writes that each year the arrival of Indian Bhojpuri speakers to Surinam in the nineteenth century is celebrated till date at Lanlarukh auditorium (Surinam). Many songs are sung on that day in memory of the contractees who came to Surinam. One of the songs by contractees, reads like this:

Chhod aili Hindustan babuwa petwa ke liye.

Chhodni maiya, bapuwa bandhu sara pariwaar ki

chhote mile ki aas.

(I left India for employment in another country

I left my mother, father, friends and all family members

I have no hope to meet them again) (p.229).

As Nirbhik writes further in his account, in Fiji, around 468 Bhojpuri speakers were brought from India in a ship called Lionidaas. They reached Fiji on $15^{\text {th }}$ May, 1879 and there they were known as bandhua shramik (bonded labourers). More Bhojpuri speakers were brought under daas pratha (slavery system) from 1879 till 1916 to Fiji to work as labourers.

\section{Dr. Chandra Prakash Jain: Pravaasi Bhartiya Kaha aur Kitne?}

In a similar context, Dr. Chandra Prakash Jain has written a travel account, 'Pravasi Bhartiya: Kaha aur kitne'. Jain blames the caste system prevailing in India for deterioration of socio-political conditions which was going on for around two thousand years even before the British colonized India. The situation in India was further exploited at the hands of the British Raj. Bhojpuri speakers, who were mostly from lower castes were landless and in an urge to earn some income to feed their family, they were ready to work first at British plantations in Assam and then were even ready to migrate to other countries to work at plantations, where they were called 'coolies'. These aspects points towards dimensions of caste in India and even economic backwardness in the country, poverty being rampant. (p. 250) 
The reasons why Bhojpuri speakers went to another country during British rule is varied in nature. It was in those times in India when zamindari system (landlord system) was seeing upsurge, and thus, more and more poor farmers were losing their lands to the zamindars (landlords). In the nineteenth century, India even witnessed drought and hunger situation which further worsened existing situations in the country. The time period between 1860 to 1910 was the most difficult period which India witnessed with regards to existing poor economic, social and political conditions.

Amongst the landless labourers, the most suppressed were people belonging to what is now called the scheduled caste. The Bhojpuri speaking Indians who travelled to colonized islands constituted much of the people belonging to scheduled castes. Jain supports his argument by giving an example to show the percentage of population of Bhojpuri speakers sent as plantation labourers and the castes to which they belonged. He states that speakers belonging to Brahmin and other upper castes were $\mathbf{1 6 . 4}$ per cent, castes related to land and farming were $\mathbf{3 7 . 2}$ per cent, labour castes 10.4 per cent, scheduled castes 37.2 per cent. This was the population structure of speakers sent to Guyana. According to him, this was the percentage of caste population which was similar for almost all islands such as Fiji, Surinam, and Trinidad where Bhojpuri speakers were sent. From the perspective of religion, he adds, 84 per cent were Hindus, 16 per percent were Muslims and Christians. Besides Guyana, this religion structure was seen in Trinidad, Fiji and Surinam too. (p.253).

\section{Dr Kamta Kamlesh: Fiji Mein Kabir Panth ka Udbhav aur Vikas}

Dr. Kamta Kamlesh writes that saint Kabir's stories were born the day Bhojpuri speakers from India arrived in Fiji as labourers to work at different British plantations. In this regard, in Fiji, she mentions about Shri Gyanidas who wrote in a Hindi periodical named Shantidoot. She writes that these Bhojpuri speakers were known as girmit and they came to Fiji in a ship called Lionidas. The first day they arrived in Fiji was $15^{\text {th }}$ May, 1879. Even later, many Bhojpuri speaking labourers arrived in Fiji by various ships. They were called Kabir panthis (followers of saint Kabir). It can be argued that most of the Bhojpuri speakers were brought from cities in India such as Gorakhpur, Ballia, Basti, Jaunpur, Gonda, Faizabad, Sultanpur, Azamgarh, Pratapgarh, Dewaria, Patna, Chhapra etc which were the places where Kabir travelled and sung songs and thus all Bhojpuri speakers from these areas were followers of Kabir. (pp.175-176)

Many followers of Kabir travelled from India with musical instruments such as khajdi, tumda, dholak, dandtaal, etc and sang songs of Kabir on their way to travel to another country, Fiji. The followers of Kabir could be seen walking barefoot in Fiji, singing songs of Kabir. However, in the present times the followers of Kabir can be seen in Fiji in temples. They used to refer to Kabir as 'Kabir Saheb' (Sir Kabir) and the term 'Kabir Saheb' is written at many places in Fiji to show respect to saint Kabir. The Bhojpuri speakers who went to Fiji as labourers were uneducated or less educated and poor. They were followers of Kabir's song which reads as, Kagaj chhuo naahi kalam (neither touched paper nor pen), as Kabir used to travel and sing songs of knowledge. They were eager to submit themselves in devotion to Kabir and were polite and calm in nature. These songs of Kabir in every way provided them with a sense of comfort and strength while they undertook the difficult travel to Fiji. (p.178)

\section{Dr. Shri Vilas Tiwary: Bhojpuri Kshetra ki Jatiya Pehchaan}


Dr. Shri Vilas Tiwary writes, though British rule was everywhere in India, the British were particularly observant about the hard working nature and poverty of the Bhojpuri speaking Indians. It is in this light that the Bhojpuri speakers were sent to British plantations set up in Trinidad, Fiji, Guyana, Surinam, and Mauritius to work as cheap labourers. The Bhojpuri region in India was inhabited with a huge population. Though they were poor and landless, they were brave and thus posed a threat to the British raj. The British tried to fulfill a dual purpose by making a diplomatic plan. The first was to send Bhojpuri speaking Indians to their plantations in various countries as Bhojpuri speakers were hard working and could provide cheap labour owing to their status of unemployment and poverty in India. The second was to send as many Bhojpuri men as possible to plantations in other countries so that Bhojpuri unity and thus the brave and fighting population of this region could be destroyed. However, it is interesting to note here that despite the efforts to destroy Bhojpuri unity since 1816, the British saw a huge uproar from the Bhojpuri region in 1857, during the first war of Independence. Two of the great warriors of 1857 in India, Mangal Pandey and Kunwar Singh originally belonged to the Bhojpuri region who presented their bravery in front of the British army. (pp. 256-257)

In this context, Tiwary adds a song in Bhojpuri, sung by Bhojpuri contractees:

'sonwa karan ailo ram, ehi re mirich des,

se gali gaile sonwa sareer, ehi re mirich des'

(We came to look for gold and earn money here in Mauritius.

However, we were made to work so hard

that our precious body which was like gold, started to deteriorate.

This is Mauritius) (p.261).

Terms such as girmitiya and contractee, came into use to refer to Bhojpuri speaking Indians who travelled as labourers to the British plantations in various colonized islands during the British rule in India. The stories of pain and separation had no words to define their intensity on many occasions. The labourers suffered mental torture and sadness of leaving their loved ones behind and were sent in thousands to various island countries. They faced long journeys on ship which were filled with hopelessness. One of the songs which defined these stories of pain and separation is presented here:

'firangiya ke rajuwa me chhoota mora desuwa ho,

gori sarkar chali chaal re bidesia,

boli hume dekh kar arkaati bharmay ho.

Anguthwa lagay del haar ke bidesia,

Calcutta par jao paanch saal re bidesia'

(During British rule in India, I had to leave my country.

The British played tricks and made us put thumb impression

on contracts to work as labourers in their colonized islands.

The situation better than this, was to go to Kolkata for five years

and earn money, like Bidesi, a character of Bhikhari Thakur's ${ }^{2}$ play) (p.261). 


\section{Conclusion}

In the present era, all the countries mentioned in this paper, such as Mauritius, Fiji, Guyana, Surinam, Trinidad, Tobago are independent. The Bhojpuri diaspora, who went to these countries in the pre-independent period, plays a significant role in various developments in these countries since that period till date. The stories discussed in the paper take us towards a range of emotional outbursts while travelling to another country which each individual traveller faced. Their separation from families, thinking about life and livelihood in another country, the long and difficult journeys were some of the thoughts going on in each traveller's mind and these have been discussed through travel literature. At times they cried, while at other times, they joined each other as a group to struggle through their journey together with their co-travellers. Singing songs, chanting the Ramayana and the Bhagvad Gita, singing songs of saint Kabir, were some of the entertaining aspects of their journey which bound them together.

In this context, Dr. Shri Vilas Tiwary concludes that though the journeys of the Bhojpuri diaspora were difficult and sad in the initial phase, in the present scenario, however, the Bhojpuri diaspora settled in countries such as Surinam, Trinidad, Fiji, Mauritius, Guyana, are well established. At the political platforms of these countries too, it is the Bhojpuri diaspora which dominates. But their memories of the long journeys are still fresh in their minds. Even after being settled in another country, the Bhojpuri diaspora still pay respect to their home country, India. Whenever any individual comes back to visit their home country, India, they visit their native places too, to revisit their old memories.

Dr. Kamta Kamlesh writes, in the present time, the followers of Saint Kabir are educated, with a very less number not educated. However, this was not the situation in the initial phase when Bhojpuri speaking Kabir followers came to various countries such as Fiji, Mauritius, Trinidad, as most of them were uneducated and knew nothing but songs of Kabir which they heard at their native places before the long journey took place.

To conclude his travel account, Dr. Rasik Bihari Ojha Nirbhik writes, though contractees suffered miseries in another country initially, later they rebelled against the British. Whenever any British used to exploit any woman labourer, the Bhojpuri speakers used to fight against that exploitation. Today all these countries are independent. Fiji, Mauritius, Trinidad, Tobago and Surinam, where Bhojpuri speakers saw their days of struggle in new countries after they travelled there under a five year agreement when India was colonized under the British, as well as the countries to which they travelled, were also colonized island countries.

In this regard, it can be argued in the Indian context, while most of the travel accounts discussed in this paper specify at the end that though Bhojpuri language got its due respect and recognition in another country, it is yet to achieve its recognition in its home country, India. There have been demands in India to include Bhojpuri in the Eighth Schedule of the Indian constitution. Till date, since independence, twenty two languages have been recognized as official languages in India. However, in the contemporary scenario, there have been demands from thirty eight more languages to be included in the Eighth Schedule of the Indian Constitution and achieve the status of official language, and Bhojpuri is one of them. 


\section{Notes:}

${ }^{1}$ Diaspora is a term which implies overseas Indians, or Pravasi Bhartiya as termed by Ministry of External Affairs, India. Pravasi Bharitya Divas is celebrated on $9^{\text {th }}$ January each year to celebrate the contribution of overseas Indian in the development of India. More information on the meaning of this term can be seen at www.mea.gov.in.

${ }^{2}$ Bhikhari Thakur is a notable Bhojpuri playwright who wrote a famous play Bidesia, defining life of a migrant to another city. He has written twenty nine plays which can be seen in a book, Bhikhari Thakur Rachnavali, published by Bihar Rashtrabhasha Parishad, Patna (Bihar), India.

\section{References}

Grierson, G.A (Ed.). (1903). Linguistic Survey of India (vol.5, pt.2, Indo Aryan Family, Eastern Group: Specimens of the Bihari and Oriya Languages). Calcutta: Office of the Superintendent, Government Building.

Shandilya, R. (Ed.) (2004). Vishwa Vyapini Bhojpuri. Varanasi: Sanjay Book Centre.

Thompson, C. (2011). Travel Writing. New York: Routledge. 